\title{
The Question of Existence: Revisiting Black Women in Go Tell it on the Mountain
}

\author{
Brighton.A.Rose, V.Chanthiramathi
}

\begin{abstract}
Women had been always at the receiving end of the society and she is forced to cater to the needs of the society she is part of. Existing as an individual with the basic rights and freedom is the bigger question for women as she is always an object of oppression in almost all the society, in particular the 'Patriarchal society', in which she is expected to be under the control of a man and tender to the needs of the man and those around him without question. Racism along with Sexism in America ensured the suppression of black women and the white women to a certain extent. The research paper titled 'The Question of Existence: Revisiting Black Women in Go Tell it on the Mountain' makes an study on the state of the blacks in general and attempts an in depth analysis on the state of black women in America in the 1920s and the various forms of oppression they endured, from physical to psychological oppression, from skinning to caning to the violence that they have to be victims even after a very long time is studied in this paper.
\end{abstract}

Key words: Racism, Sexism, Patriarchy, Existentialism, Blacks, Oppression.

\section{INTRODUCTION}

Fiction being a medium of oppression has been a very powerful and effective genre in world literature. Fiction had been and always will be an integral part of any culture it represents, highlighting the religious convictions and philosophical approaches and the social and political changes that exist in the region the novel represents. Writing has been employed as a tool of survival by the writers by bringing out the suppression that the individual and the society he is part of endures.

The research work makes a study on the two controlling forces of the blacks in America, that is Racism and Sexism and how they had a dominant control over the blacks, in particular the black women. Racism is the system of dominance over the colonized blacks in the name of colour. Sexism in general is the system of subjugation of women mostly by the system of patriarchy, and at times by their own fellow women. Blacks, in general had been victims of Racism and Sexism similarly, but Black women have been victims of Sexism, that too triple oppression while the white women have been a victim of sexism alone. Another major issue dealt with in this research paper is the role of religion in

Revised Manuscript Received on November 11, 2019.

Correspondence Author

Brighton.A.Rose, PhD Scholar, PG \& Research Department of English, V.O.Chidambaram College, Manonmaniam Sunderanar University, Abishekapatti, Tirunelveli, India.

Dr.V.Chanthiramathi, Research Guide \& Associate Professor, PG \& Research Department of English, V.O.Chidambaram College, Manonmaniam Sunderanar University, Abishekapatti, Tirunelveli, India.

controlling and subjugating the masses. Religion had been employed by the whites to justify the system of racism as something that God had asked them to do. The paper also portrays the system of corruption that existed even within the black church and how the people, in particular the women were exploited in the name of religion.

Existentialism is a philosophy which developed in the nineteenth century that emphasises individual freedom, existence and choice. It focuses on the question of human existence. It deals with the problems concerning the individual and the society. It provides greater importance to the psychological state of the individual than his/her physical state. It expounds on the inner trauma of the victim. American black existentialism focuses mainly on the inner psyche of the American black, the problem he / she undergoes in the society, the suppression that she endures to the extreme state of curtailing his / her own identity and freedom. It also focuses on thee attitude of the whites against the blacks. More importantly, it focuses on the state of the blacks towards their own folk, the state of the black man towards her own woman and how she endures the sufferings in life. This philosophy has been used by writers such as W.E.B.Du Bois, James Baldwin and Ralph Ellison to a greater extent.

Racism and Sexism were and still to an extent the controlling agents in the American system. Racism is the feeling of superiority of a race over the other. In the American context, the Whites were the oppressors and the blacks and the mixed race were the objects designed to endure any level of suffering. The black people who were brought into America came from societies, rich in culture and artistic development, but are forced to undergo humiliation to the greater extent. The white settlers of America bought blacks like cattle for farming purpose. In order to capture slaves, violent armed raids were carried out against African settlements. Those captured were gathered like animals. The captives were beaten to death or burned alive; they are hung by being nailed, or their ears cut off and fed.The mode of oppression practiced on the blacks was not only physical, but also psychological to the extent that they are still victims undergoing certain forms of oppression. The black women in America were the victims of one of the most sustained campaigns of sexual aggression in the history. Black women were labelled promiscuous and sexually base. Slavery laid the foundations for the present terror and lawlessness practiced against the black people in America. And after all these years of freedom and liberation, black is still a colour which represents death and sorrow and white is used as a colour of purity.

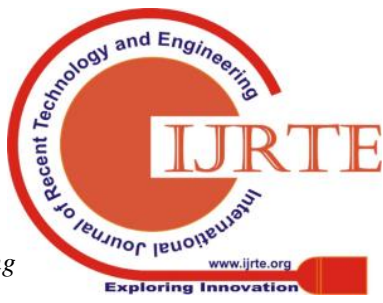




\section{The Question of Existence: Revisiting Black Women in Go Tell it on the Mountain}

Religion has been employed as a mass tool of suppression, favouring a particular sect of people and subjugation the 'other', which includes the majority of the people. Christianity has been the major religion in America. The spiritual creations of African American religion were born out of their prayers for mercy. Moreover, the religion Christianity states the birth and subjugation of the woman in the chapter, Genesis. The moment the woman was made out the flesh and bone of the man, marks the beginning of suppression of women. Furthermore, the suppression of women continued when she sought to her own desires against the will of God. And this state of suppression which started is still carried out in one form or the other. Genesis 2:23 of The Holy Bible which states:

This is now bone of my bones
and flesh of my flesh; she
shall be called 'woman' for shall be was taken out of man.

Racism - the belief that a person because of the colour of their skin are superior to those of a different colour and therefore are justified, through manipulation and control of the power at their disposal, in having superior economic, social and political positions. So strong was the feeling among the great mass of White people that they are superior to the blacks. Patriarchy or the domination of women existed along with the suppression of the blacks by the white women Racism is not just a system of segregation and a problem of the century. The subordinate position of black people who were treated as mere objects and certain steps were employed by the masters to train the black slaves to hold them down by brute force and psychological warfare, and the blacks were forced to follow in similar to the instructions in taming an animal. The whippings, the punishments were work disciplines. Professor Kenneth Stampp makes a note of this in his, The Peculiar Institution:

To maintain strict discipline, to implant in the slave a sense of inferiority born of his African ancestory, to awe the slave with the sense of the power of the White people, to train the slave to believe that his interest and that of his master are one and the same, and to instill in the slave a sense of his helplessness. (78)

Most white people saw the source of the racial problem in Black people, not in their own people or the corrosive effects of their institutions. Black people became the dark repositories into which the white people attempted to project their fears and upload their phobias. James Baldwin makes a note of this through the black janitor in the movie They Won't Forget, in the motion picture I Am Not Your Negro. In the movie, a white girl has been raped and murdered and her body was recovered from the premises where the black character, Clinton Rosemound who played the role as a janitor and he beautifully brings forth the pain and trauma of a common black man.

The experiences through which Black people went during slavery, the systematic and sustained victimization savagely applied, were probably unparalleled in all of modern and most of ancient history. Booker Washington in his Up from slavery, provides account of the Black slave's state as an exploited individual: ...racism hung like an incubus over White Americans, causing most to persist in regarding Black people as objects to be used and exploited on all levels of contact, whether in education or in politics, in economics or in art, in "freedom" as in slavery. (36)

Baldwin a victim of white power, degradation and brutality of the Harlem reflects in his novels reflect the difficulties of individuals for whom the question of personal identity bears an urgent relation to that of social survival because of their colour or sexuality. Baldwin makes a similar remark in his novel, Giovanni's Room: "People invent categories in order to feel safe. White people invented black people to give white people identity." (88)

Go Tell it to the Mountain is one of the few narratives in African - American literature that deals about Racism and Sexism simultaneously. Racism and sexism cannot be separated particularly in the American context as it is interwoven with each other. Claudia Tate in her Freud and His Negro: psychoanalysis as Ally and Enemy of African Americans explores the racist dimensions and helps to attain clarity on the effects of racism.

White patriarchal power uses its fantasies to oppress the real life of those who are not male and/or white. However, victims unconsciously participate in their own subjugation and similarly oppress others. Psychoanalysis could tell us much about these processes. (60)

James Baldwin in the novel, brings forth the idea of cultural segregation, in particular the idea of racism prevalent in the United States, through the character of John Grimes in the novel. James Baldwin provides an in-depth sketch of the place they are part of and explains how places played a major role in dividing the people. The idea of segregating people into North and South regions, in other words, while the Northern states of America used the blacks as domestic slaves for their agricultural practices, the Southern states, because of being an industrial state started abolishing slavery, and became abolitionists. James Baldwin, in the novel makes an analysis of the city of New York and in particular 'Broad Way' through the character of John Grimes and picturize the place not only in a religious context but also on how it reacts to the blacks. He brings forth the idea of racism that is prevalent in New York.

He remembered the people he had seen in that city, whose eyes held no love for him. And he thought of their feet so swift and brutal, and the dark grey clothes they wore, and how when they passed they did not see him, or, if they saw him, they smirked. And how their lights, unceasing, crashed on and off above him, and how he was a stranger there. (38).

Sexism is another important factor of suppression of women. The idea of suppression by sexism has been followed by many communities, in particular the American community. The cult of 
domesticity for the woman was a way of pacifying her, giving her work equally important as the man's, but separate and different than the man. The women in the American community were victims, but the black women are the direct victims of sexism. The women are affected not only physically nut also psychologically. The black children were separated from their mothers and their families destroyed.They are victims of triple oppression, oppressed by their White master and mistress and her own man. Bell hooks in her Feminist theory: from margin to center brings forth a similar idea:

...black women are in an unusual position in this society... White women and black men have it both ways. They can act as oppressor or be oppressed. Black men may be victimised by racism, but sexism allows them to act as exploiters and oppressors of black people. (15)

The White women were victims, though they were not victims of racism to a greater extent, were victims of sexism, as they are dominated by their white men and even at times by their black slaves. "Slavery is terrible for men; but it is far more terrible for women. Superadded to the burden common to all, they have wrongs, and sufferings, and mortifications peculiarly their own"(86), which finds its place in Harriet Jacobs Incidents in the Life of a Slave girl, which also brings out the intensity of the Slaves, Slave trade and most importantly their inner urge for survival.

Gender discrimination is one of the major issues in Racism. Slavery was not an unrecorded experience and slaves were not silent at all times. Blacks were the victims of oppression. But the severity of the oppression varied between the men and the women. Black men were victims of double oppression, in which they were oppressed by the white men and women while the black women were victims of triple oppression, where they are oppressed not only by the White men and women, but also by the black men. The black women force their own kind into slavery and at times they discriminate their own race. Frederick Douglass makes an account of the pain and pathos of the black mothers in his novels, Narrative of the Life of Frederick Douglass, An American slave as

The heart is desolate. The unconscious children who once sang and danced in her presence are gone. She gropes her way, in the darkness of age, for a drink of water... the grave is at the door and now...my poor old grandmother, the devoted mother of children, is left all alone, in yonder little hut, before a few dim cinders. (157)

In the novel Go tell it to the mountain, James Baldwin brings forth the account of black women. Frederick, after the birth of Gabriel in the family, Florence felt as if she had lost her status in the family to the state that she even wished that he was never born. She lost almost all her rights, which includes her right to education. Although Florence was five years older than Gabriel, it was the boy's future that mattered more to their mother. She made Florence do most of the work, forcing her to wait on Gabriel. While she encouraged Gabriel's education (though to no avail, for he was wild and un studious), she denied Florence any schooling.

Florence is one of the major characters in the novel who had started her life in hatred and fear, fear of the white community, fear from the own community. She raises her voice on how religion had helped shape her life. She is like any other women who has underwent various things and met various people in life just for the sake of attaining a temporary state of happiness in her life. Through Florence, we learn about the life of her mother, who was a victim of slavery, a victim in which she was not only the sufferer but also her children who were forcibly removed from her. In Florence's mind, her mother was always an immeasurably old woman telling stories of slavery and Exodus in the family's cold cabin, interweaving the Bible with her own life.:

On this plantation she had grown up as one of the field - workers, for she was very tall and strong; and by the by she had married and raised children, all of whom have been taken from her, one by sickness and two by auction; and one, whom she had never been allowed to call her own, had been raised in the master's house. (78)

Florence, too was a victim of gender discrimination that resulted because of Racism. When she was twenty-six, she was employed as a cook and a serving - girl for a large white family in the town, while her mother was terribly ill at that point of time. The white master of the household asked her to be her concubine and that she can end the terrible state her family has been going through, "her master proposed that she become his concubine that she knew her life among these wretched people had come to its destined end" (85).

Sexism and its impact upon the black women are picturized in the novel. Suppression in terms of physicality is one of the major violence that in committed on a woman. The violence upon women, in particular the black women is so gross that she is considered less than an animal. She is nothing but a toy in the eyes of the men. Sexual intimidations made by the black men towards a black woman is portrayed through the character, Florence. Frank often came home drunk and senseless and even at this state, he tries to indulge in sexual relationship with Florence. She feels humiliated at being a toy to satisfy the needs of Frank. She did not want to be touched but still she was forced. She picturizes one of the many occasions,

'Let me alone, Frank. I want to go to sleep'.

'No you don't. You don't want to go to sleep so soon. You want me to talk to you a little. You know how your baby loves to talk. Listen' 'You stink of whisky. Let me alone.' (99)

Black women being a victim of physical violence is not the only one who suffers. The people who are close to the victims also suffer the fate of the women indirectly. Black women are victims of direct oppression, but the ones around her also becomes victims. This is evident in the novel. Deborah, another neighbour of Florence and who later married his brother was also a victim of 


\section{The Question of Existence: Revisiting Black Women in Go Tell it on the Mountain}

physical violence that resulted because of racism. It did not only disturb her in all possible ways, but also resulted in the death of his father:

Their neighbour Deborah, who was sixteen, three years older than Florence, had been taken away into the fields the night before by many white men, where they did things to her to make her cry and bleed. To-day, Deborah's father had gone to one of the white man's houses, and said that he would kill...They had beaten him and left him for dead. (77)

The violence upon the black women is not always the result of the white folks. It can also be forced upon by their own black folk. Elizabeth, in the novel was a victim of violence inflicted upon her by her own aunt. She cannot experience the love and care she has experienced before. She cannot be the normal person she was before and all her happiness are thrown to the dust. Her mother dead, her Father banished and she was forced to live in the shadow of her aunt. From the doings of her aunt, she understood that she had loved her sister, but not her husband and this made him mean towards her father. Elizabeth was forced to lead a life of imprisonment.

She merely regarded her aunt with a wide eyed, insolent stare, meant at once to register her distain and to thwart any pretext of punishment...As the years went on, her aunt seemed to gauge in a look the icy distances that Elizabeth had put between them, and that would never be conquered now. (181)

Religion has been a tool of oppression and subjugation for a very long time. As Karl Marx observes, "Man makes religion, religion doesn't not make man... It is the opium of the people"(3). Religion was used to control the black slaves in America. A book consulted by every planter and slave holder was the Cotton Plantation Record and Account Book, which provides account of their justification of slavery and the training of their slaves: "You will find that an hour devoted every Sabbath morning to their moral and religious instruction would prove a great aid to you in bringing about a better state of things amongst the Negroes." (85)

Religion has been used by many religious men as a weapon to commit evil deeds and still enjoy a privilege of being a good and holy man in the society. In the name of religion, people not able to satisfy their body needs succumb themselves to women to satisfy their needs. Baldwin writes in his, The Fire next time: "there was no love in the church. It was a mask for hatred and self - hatred and despair." (63) Moreover, in the novel, Esther gets pregnant because of the illicit relationship with Gabriel. Gabriel, the so - called religious person is unable and unwilling to face the darker side of his own self. In the novel, months later when Esther tells him that she was pregnant with his child he was shocked and starts acting like a good man with a pure soul only to serve God. At first, Gabriel refused the child to be his own. But Esther was so adamant and sure about it. He did not want to leave his reputed life and a good woman like Dorothy for Esther. Gabriel forces Esther to leave the town in order to maintain his reputation as a religious man. Moreover, in the novel he despises Elizabeth, as well as Deborah, his first wife because in his eyes, they are fallen women.

'Girl,' he said, 'does you reckon I'm going to runoff and lead a life of sin with you somewhere, just because you tell me you got my baby kicking in your belly? How many kinds of a fool you think I am? I got God's work to do - my life doesn't belong to you. (151)

Gabriel the character is portrayed to be a religious person who is black with a white attitude. The American whites have the tendency or attitude to consider themselves superior to the other races, may it be blacks, the colored or the native red Indians. Robert Bone in his Images of the Negro in American Literature, says that Gabriel's attitude in the novel is white. "He thinks that he is immaculate, so to say "white," without a stain. If he is the saintly, the saved, the elected, then logically there must be the evil, which is the black." (70)

The blacks though they are portrayed to embrace the blackness in them that helped them built an integrity among their community, at times hate the blackness in them and start to follow the qualities of the whites. Florence, in the novel is portrayed to be black women, who hates the blackness in her and is picturized to be using creams and cosmetics in order to be like the white women. She even hates the black community in which she is part of. She is of the opinion that being a white would acquire better respect in the American society.

The attitude of ownership, of holding an almost divine right over the destinies of the black people, seemed to have deeply rooted in the White American consciousness. In fact, most White Americans seem to believe sincerely that White people, irrespective of the age are better than the other people and that the lives of the White Americans are more valuable than the lives of any other sect of people.

The state of the blacks can be brought under the term "subjectivity". The state of their consciousness is mostly negative, as they have been living a life of slavery and they get used to the treatment and sufferings in the hands of their white masters. Black consciousness is the awareness of one's identity as a black person, and is itself described as a double consciousness. Blacks were the foremost and the direct victims of American Racism.

Blacks were the oppressed class in the American context. Abraham Maslow's Theory of Human Motivation as stated in his text book Hierarchy of Needs: A Theory of Human Motivation clearly points that human beings have innate needs which have to be fulfilled in order for them to feel secure and satisfied. This being the case, the connection between the fact that the blacks were enslaved and their desire to attain liberty is firmly attached to their means for survival. To survive, People tend to use any means. In the American context, the black used different means to survive the white oppression. The Patriarchal domination towards not only their own folk but also towards their slaves has been exposed by the author. The race for survival makes more sense to the Blacks who had no other choice but to employ all their means at their disposal to live as free human beings. This is an essential motivator of 
their survival. Religion was used as a mode of promoting slavery. The Church (the white church) promoted the enslavement of the black people, but on the other hand, Religion was also used as a survival tool by the blacks, as Religion was the only thing they can resort to, the only thing that can offer them comfort, as Religion was the only means of uniting the people and the role of the Black church from the small regions of Harlem to achieve national importance. Church served as a survival strategy even for Baldwin, and 'safety' and 'church' are synonymous to him.

In order to survive amidst the white patriarchal hegemonies that existed during the time of slavery, the blacks basically tend to follow two forms of survival

i. By physical resistance.

ii. By employing means of deception.

There are records of several physical revolts against the white oppression that existed during the times of slavery and even after the slavery was abolished. Nat Turner, is one of the persons who revolted against the white supremacy, and this has been brought out in the novel Dred by Harriet Beecher Stowe and the ways of how they survived in the swamps of America. While this was employed as a direct resistance against the White supremacy, the blacks also tend to means of deceiving their white masters.

Afro-American existential philosophy emerged out of the experience of the diasporic Africa. It is a branch of Africana and the black philosophies of existence. The individual's longing for order and freedom collides with the real world's system of suppression and lack of order. Existentialism in the Afro - American context deals with the existence and meaning in life of the black folks and is used to bring out the racial significance and meaninglessness life of the black community.

\section{RESULTS AND CONCLUSION}

This research paper analyses in depth the sufferings and oppression undergone by the black community, in particular the black women. Furthermore, it emphasizes on the liberation of all the black people in the world from oppression which has been deep rooted within its people. But, after all these years of freedom and liberation, are the blacks really enjoy every aspect of leverage and freedom. Does the women from the black community considered and treated equal as a women in equivalent to the women of white community? Are the people from the black community provided equal opportunities that are provided to a person of white race? If all these questions are answered it will to an extent help in leading the nation towards racial integrity and a better world.

\section{REFERENCES}

1. Baldwin, James. Go Tell It to the Mountain. Grosset \& Dunlap, 1953

2. Baldwin, James. Giovannis Room. Everymans Library, 2016.

3. Baldwin, James. The Fire next Time. Vintage Books, 1992.

4. Affleck, Thomas. The Cotton Plantation Record and Account Book. Published by Thomas Affleck, 1859.

5. Bone, Robert. Images of the Negro in American Literature. Edited by Seymour L Gross and John Edward Hardy, University of Chicago Press, 1966.

6. Douglass, Frederick. Narrative of the Life of Frederick Douglass, an American Slave: Written by Himself. Newcastle Group, 2014.

7. Hooks, Bell. Feminist Theory: from Margin to Center. Routledge, 2015
8. Jacobs, Harriet Ann. Incidents in the Life of a Slave Girl. CreateSpace Independent Publishing Platform, 2014.

9. King James Bible. Holman Bible Publishers, 1973, King James Bible.

10. Marx, Karl. "Critique of Hegel's Philosophy of Right." Marx's Critique of Hegel's Philosophy of Right, 1843-4, Deutsch - Franzosische Jahrbucher, 2009 https://www.marxists.org/archive/marx/works/1843/critique-hpr/.

11. Maslow, Abraham H. Hierarchy of Needs: A Theory of Human Motivation. Mansfield Center: Martino Publishing, 2013.

12. Peck, Raoul, director. I Am Not Your Negro. I Am Not Your Negro, Velvet Film, $10 \quad$ Sept. 2016 , https://www.netflix.com/in/title/80144402? source=35.

13. Stamp, Kenneth M. Peculiar Institution: Slavery in the Ante-Bellum South. Vintage Publishers, 1989.

14. Tate, Claudia. "Freud and His 'Negro': Psychoanalysis as Ally and Enemy of African Americans." Journal for the Psychoanalysis of Culture \& Society, vol. 1, no. 1, 1996, pp. 53-62. PsycINFO, https://psycnet.apa.org/record/1999-15742-004.

15. Washington, Booker T. Up from Slavery: an Autobiography. HardPress Publishing, 2013. 